\title{
Imagining Economic Space in Colonial India
}

DOI:

10.1108/S0743-41542018000036B008

\section{Document Version}

Accepted author manuscript

Link to publication record in Manchester Research Explorer

\section{Citation for published version (APA):}

Velkar, A. (2018). Imagining Economic Space in Colonial India. Research in the History of Economic Thought and Methodology, 36B, 109-128. https://doi.org/10.1108/S0743-41542018000036B008

\section{Published in:}

Research in the History of Economic Thought and Methodology

\section{Citing this paper}

Please note that where the full-text provided on Manchester Research Explorer is the Author Accepted Manuscript or Proof version this may differ from the final Published version. If citing, it is advised that you check and use the publisher's definitive version.

\section{General rights}

Copyright and moral rights for the publications made accessible in the Research Explorer are retained by the authors and/or other copyright owners and it is a condition of accessing publications that users recognise and abide by the legal requirements associated with these rights.

\section{Takedown policy}

If you believe that this document breaches copyright please refer to the University of Manchester's Takedown Procedures [http://man.ac.uk/04Y6Bo] or contact uml.scholarlycommunications@manchester.ac.uk providing relevant details, so we can investigate your claim.

\section{OPEN ACCESS}




\section{Imagination and Rule: Visualising Economic Space in India $\left(18^{\text {th }}\right.$ $-20^{\text {th }}$ century)}

Dr. Aashish Velkar

University of Manchester

Samuel Alexander Building

Oxford Road

Manchester M13 9PL

+44(0) 1612753111

Aashish.Velkar@manchester.ac.uk

in Research in the History of Economic Thought and Methodology: Including a Symposium on the Work of Mary Morgan: Curiosity, Imagination, and Surprise, Volume 36B (2018), 109-128

Author accepted version: 7 March 2018 


\section{Abstract:}

This article argues that the process of imagination is moulded by the intersecting notions of space, time, and measurements. It shows that economic spaces are shaped by notions of particular space-time held by historical actors and by imaginations of their past and future fictional spaces. The case study of colonial period South Asia examines how financial accounting and other measurements were co-opted to give form to future 'fictional' expectations. South Asian economic spaces are shown to be the locus for control and dominance of future economic relationships, which were visualised in particular ways by the colonial rulers.

A conclusion reached is that economic spaces are not just enclosed spaces within borders where economic activity occurs shaped by the dominant culture and economy of a state. The economic spaces in colonial India were sites of economic conflict and violence, where contesting notions of economic time collided, and where widely contrasting economic futures were imagined. Indian nationalists looked into the past to spur their imagination of a different future for India. In fact, the conflict or violence that was part of the recasting of India's national economic space was not entirely between racial groups (European colonists and native Indians) or strictly between economic classes (bourgeoisie upper castes and proletariat lower castes). Contrary expectations amongst the nationalists themselves are apparent. The process of imagination reveals the ensemble of cultural, social and technical practices that actors use to in giving form to fictional expectations of the future and the spatialisation of economic spaces.

Keywords: economic spaces, measurement, nationalism, India, colonialism, economic planning 


\section{Introduction}

This article is inspired by the ideas of Mary S. Morgan, particularly her work on how economists imagine the economic world and then make images of it. In The World in the Model, Mary describes the 'joint processes of visualisation - imagining and making an image' and shows how 'as scientists imagine their world, and make images of that world in new forms, they also form new concepts to work and argue with. ${ }^{11}$ This article considers how historical actors in colonial India imagined their economic world, the devices they used to give shape to their imaginations, and how such visualisations led them to new concepts and knowledge regarding the economic spaces they imagined. Based on this case analysis, I argue that the process of imagination is moulded by the intersecting notions of space, time, and measurements; that the making of economic spaces and narratives of the past shaped how historical actors imagined their futures.

What follows is a review, admittedly in an impressionistic fashion, of how historical actors (merchants, travellers, colonial administrators, politicians, social reformers, and other non-economists) used measurements to visualise economic spaces, including commercial and financial accounts, travel accounts, and statistical data. Imagination here is related to the visualisation of economic spaces as 'calculable spaces,' whether they were at the level of territories ruled by states or commercial enterprises on a much smaller scale. ${ }^{2}$ Unsurprisingly, western economic thought shaped much of the official thinking and the colonial state's visualisation of economic spaces in India in the late eighteenth and early nineteenth century. But, Indians educated in the western thought, and who were also exposed to the ideas of

\footnotetext{
${ }^{1}$ Mary S. Morgan, The World in the Model: how economists work and think (Cambridge 2012), 93.

2 Peter Miller, 'Accounting and Objectivity: The Invention of Calculating Selves and Calculable Spaces,' in A. Megill (ed.), Rethinking Objectivity, (Durham, US: Duke University Press, 1994), 239-264: 253.
} 
economists, such as Frederich List or John Stuart Mill, challenged the colonial view of India's political economy. ${ }^{3}$ These nationalists looked into the past to spur their ideological imagination of a different modernity for India - different from the universalising western models. They imagined an ancient (Hindu) political economy, critiqued the political economy that prevailed under colonial rule, and visualised a new kind of political economy for a future, independent India: particular images of the past and the present lent legitimacy to specific modes of economic planning.

The article also considers how historians have engaged with imagination in the historiography of colonial India. For instance, Gyan Prakash has claimed that 'science was pivotal to the imagination of modern India. ${ }^{4}$ Similarly, Manu Goswami is concerned with the 'official imaginary of the colonial economy' enabling state actors to 'envision' this space as a 'territorially bounded and temporally dynamic whole. ${ }^{, 5}$ The very idea of India, according to these views, is ensconced in some kind of collective imagination of spaces, an analytical category that can be studied in an empirical manner by historians. Benedict Anderson suggests that 'nationality, nation-ness or nationalism are cultural artefacts of a particular kind. ${ }^{6}$ But he gives little credit to the agency for imagination of colonial subjects compared to agency of colonials themselves. Introducing agency for imagination enables us to depart from the view that knowledge and control of colonial economic spaces required a 'narrowing of vision' wherein the chaos and illegibility of social practices needed forms of

\footnotetext{
${ }^{3}$ Prasannan Parthasarti, 'The history of Indian economic history,' in Francesco Boldizzoni and Pat Hudson (eds.) Routledge Handbook of Global Economic History (London 2016), 281-291: 282.

${ }^{4}$ Gyan Prakash, Another reason: science and the imagination of modern India (Princeton 1999), 3.

${ }^{5}$ Manu Goswami, Producing India: from colonial economy to national space (Chicago, 2004), 74.

${ }^{6}$ Benedict Anderson, Imagined Communities: reflections on the origins and spread of nationalism (London 2006) 3rd edn., 4.
} 
standardisation, meticulous recording and centralised bureaucratic monitoring. ${ }^{7}$ Such a view itself is narrow and fails to acknowledge the expectations expressed by non-dominant or nonstate actors who claim these spaces. Introducing the cultural agency of imagination and visualisation in addition to other devices such as recording, classifying, and standardising will bring historians closer to how historical actors devised ways of making sense of their (economic) world.

The following section briefly reviews some thoughts on the constitution of space-time and economic activity, and the use of measurement devices in such constitutions. Section 2 reviews some of the measurement devices used by historical actors to render economic spaces in South Asia as calculable spaces. Section 3 reviews the casting and recasting of national spaces as economic spaces, before the article concludes with key arguments emerging from this case study.

\section{Space, Time and Measurement}

Economic activity, at least capitalist activity, is a forward-looking process. This characteristic of pecuniary investment, often born out of pragmatism rather than ideology, means that economic actors use 'fictional expectations' to form images of the future states of their world. ${ }^{8}$ 'The essence of capital is time,' writes Jonathan Levy. ${ }^{9}$ Nonetheless, historical time, especially the immediate pasts of a historical society can influence the imagined future of that society; an imagined 'former' future. Reinhart Koselleck alludes to this in his observations about the histories of (European) modernity in a process he describes as the "temporalisation of history. ${ }^{10}$ Thus, the past in terms of historical institutional trajectories can inform national

\footnotetext{
7 James C Scott, Seeing like the state: how certain schemes to improve the human condition have failed (New Haven: CT 1998), 2 \& 11.
} 
developmental paths as well as shape choices in the present for historical actors. Economic time is not only forward looking but also involves gazing into the past. ${ }^{11}$

Inasmuch as economic time is a product of human capacity to imagine and make images of economic activity, economic spaces are a product of a social spatialisation process. 'If space is produced, we are dealing with history,' asserted Henri Lefebvre, further observing that the very idea of nation-space is a 'fiction projected by bourgeoisie onto their historical conditions to magnify them in an imaginary fashion. ${ }^{12}$ His Marxian perspective to history, leads him to detect class competition within economic and national spaces, making them a locus of violence and conflict: 'violence is the very lifeblood of this space', he claims. ${ }^{13}$ In the case of South Asia presented here, such violence is apparent in how colonial and nationalist groups attempted to constitute India's national spaces.

Economic spaces are thus shaped by notions of particular space-time held by historical actors; by imaginations of their past and future fictional spaces. If 'the economy' as a national social space is 'made,' as Mitchell refers to it, the economy as an artefact is as much material as it is abstract or conceptual. Historians of imperial spaces contend that an

8 Jens Beckert, Imagined Futures: fictional expectations and capitalist dynamics (Cambridge, MA 2016), 9. He uses the term 'fictional expectations' to mean images actors form of future states of the world, rather than false expectations or fantasies.

9 Jonathan Levy, 'Capital as Process and the History of Capitalism." Business History Review 91, (2017), 483-510: 487

${ }^{10}$ Reinhart Koselleck, Futures past: on the semantics of historical time, Tr. Keith Tribe (Cambridge, MA., 1985), 5

${ }^{11}$ Beckert, Imagined Futures, 3. He cites literature from historical sociology to support this. Institutional economists, to varying degrees, factor historical time into how economic actors factor the past into their actions for their future.

12 Henri Lefebvre, The Production of Space, Tr. Donald Nicholson-Smith (Oxford, 1991), 111-112

${ }^{13}$ Lefebvre, Production of Space, 276-7, 111-2 
economy, geography and empire were 'intimately and thoroughly interwoven. ${ }^{14}$ Mitchell, observing colonial spaces in Egypt, argues that many of the economic tools developed in the early twentieth century were done so to 'manage the enclosed spaces of the colonial economy and the problem of colonial rule. ${ }^{15}$ The material aspect of economic space is evident in artefacts such as the cadastral maps created by the British for Egypt and India, which delineated patterns of land ownership.

Even as maps allowed the British to construct knowledge and understanding of the empire they had carved out of geographical territories, the colonial rulers also constructed economic spaces 'by definition and default' as national economic spaces. For instance, John Maynard Keynes's book Indian Currency and Finance (1913), written during his time at the India Office, refers to the 'conceptualisation, measurement and management' of an enclosed economic and national space. ${ }^{16}$ This way of visualising economic spaces sits in contrast with Edney's remarks about the British and the eighteenth-century way of 'gazing' South Asian geographies. Whilst 'scientific and picturesque gazing' are certainly evident in early $19^{\text {th }}$ century travel accounts, such as those of Francis Buchanan (see following section), financial accounting, statistics and other similar record-keeping artefacts were also significant in establishing the economic significance of governing actions, instruments of rule, legitimacy of decisions, and a 'rational' evaluation of past actions. ${ }^{17}$

\footnotetext{
${ }^{14}$ Matthew H. Edney, Mapping an Empire: the geographical construction of British India, 1765-1843 (Chicago and London, 1997), 1

${ }^{15}$ Timothy Mitchell, Rule of Experts: Egypt, techno-politics, modernity (London, 2002), 84. ${ }^{16}$ Ibid., 83.

17 For instance, Jason Scott-Warren, 'Early Modern Bookkeeping and Life-Writing Revisited: accounting for Richard Stonley,' Past \& Present, 230, Issue suppl_11, (2016), 151-170.; Bruce G. Carruthers and Wendy Nelson Espeland, 'Accounting for Rationality: Double-Entry Bookkeeping and the Rhetoric of Economic Rationality.' American Journal of Sociology, 97 (1991), 31-69.; Anthony Hopwood, 'Accounting calculation and the shifting sphere of the economic,' European Accounting Review, 1 (1992), 125-143.
} 
Financial accounts, as material artefacts, were historically used in medieval and modern European societies to judge and hold a political elite 'accountable.' ${ }^{18}$ Such artefacts, also visible in colonial India (see section 3), went beyond just the recording of financial transactions or economic activity. They were part of a moral and cultural framework, were shaped by contingent practices and conventions, and were used as a rhetorical tool, at least to demonstrate probity, soundness and honesty. States and commercial establishments used these material artefacts of accounting, as well as the 'calculative practices' they embodied, for wider control and governance. ${ }^{19}$ In few cases, accounts were intended for use in 'promoting general well-being through its use in a knowledge-processing administrative apparatus' of European states: William Petty's political arithmetic of eighteenth-century England is an example of this. ${ }^{20}$ Nonetheless, the interplay between accounting and accountability was significant in deciding the future fate of an enterprise or nation.

Accounting and other devices of measurements were co-opted to give form to future 'fictional' expectations. These expectations were based on subjecting various fragments of economic spaces for analysis: spaces that masked not just the dominant social relationships but a 'host of them that spatial analysis can potentially disclose.'21 Economic spaces are, therefore, not just enclosed spaces within borders where economic activity occurs shaped by the culture and economy of a state's dominant centre: as the following sections show, Edney misses this crucial point of how the British mapped their empire in India. ${ }^{22}$ The economic spaces in colonial India were sites of economic conflict and violence, where contesting

\footnotetext{
18 Jacob Soll, The Reckoning: financial accountability, and the making and breaking of nations (Penguin 2015).

19 Hopwood, 'Accounting calculation', 126

20 Juri Mykkänen, “To methodize and regulate them": William Petty's governmental science of statistics,' History of the Human Sciences, 7 (1994), 65-88: 80.

${ }^{21}$ Lefebvre, Production of Space, 88

22 Edney, Mapping an Empire, 36
} 
notions of economic time collided, and where widely contrasting economic futures were imagined. When the iconic figure of Bharat Mata (Mother India) became the visual embodiment of the 'autonomy of the imagined nation' ${ }^{23}$ (figure 1), the image formed was also a vision of an economically independent nation whose future would be shaped by culturally particular notions of swarajya or political independence and swadeshi or indigenous manufactures (figure 2).

\section{INSERT FIGURES 1 and 2 HERE}

\section{Economic Spaces as Calculable Spaces}

The 'great East Indiamen' that plied the trade routes between London, the Indian subcontinent, the East Indies and the Chinese port of Canton, occupied the 'pride of place' in Britain's eighteenth-century merchant fleet. ${ }^{24}$ The trading activities that the East Indiamen could engage in, and the private business activity of the men who commanded them, were shaped by personal aspiration, collective imagination and detailed record-keeping. The record-keeping, in the form of account books helped to secure individual ships as material accounting spaces, safeguarding the security of the voyages and guaranteeing profitability of the investments. ${ }^{25}$

Travel accounts, accounting books, dictionaries, glossaries and other examples of writing and print reveal how economic life in South Asia was visualised between the seventeenth and nineteenth century. Many forms of writing cultures that became integral to

23 Goswami, Producing India, 199

${ }^{24} \mathrm{H}$. V. Bowen, 'Privilege and profit: Commanders of East Indiamen as private traders, entrepreneurs and smugglers, 1760-1813,' International Journal of Maritime History, 19 (2007), 43-88:43

${ }^{25}$ Miles Ogborn, India Ink: Script and Print in the making of the East India Company (Chicago, 2007), 50. 
western presence in India altered economic relations. Reimagined administrative practices, that were rendered calculable through record-keeping and detailed accounting, allowed new conceptual objects, such as landed property, to govern social spaces. ${ }^{26}$ Accounting could help to visualise the potential for trading and personal fortunes that could be made through private trade.

Meticulous record-keeping of cargoes carried during voyages to Asia was instituted fairly early on. By the early seventeenth century, the East India Company (EIC) had developed detailed instructions on how the quantity and quality of goods was to be checked before they were loaded on board, as well as regulations to protect the Company from private trading by its own crews. When EIC finally allowed private trade, an elaborate system of invoices, signed warrants and accounts was instituted to protect the Company's monopoly. The accounting system, with instructions on who was to be responsible for checking the weight of the cargo, the measurement standards that were to be used, how the measurements were to be made and recorded in the account books, and so on, was designed to 'allow the contents of each ship arriving in London to be known in detail, permitting an accurate account of the voyage. ${ }^{27}$ The record-keeping practices - the calculative practices that Hopwood mentions - enabled the ship and the voyages to be cast as calculable spaces enabling those who encountered these records to visualise the economic potential of the South Asian regions. ${ }^{28}$

${ }^{26}$ Bhavani Raman, Document Raj: writing and scribes in early colonial south India (Chicago 2012), 15.

27 Osborn, India Ink, 51

${ }^{28}$ Peter Miller, 'Accounting and Objectivity: The Invention of Calculating Selves and Calculable Spaces,' in A. Megill (ed.), Rethinking Objectivity, (Durham, US: Duke University Press, 1994), 239-264; Hopwood, 'Accounting calculation'. 
The territorial and commercial expansion secured by the EIC during the eighteenthcentury helped to expand both the Company and the private trade. The crews of the East Indiamen depended upon their ability to secure access to credit, capital and knowledge of a variety of different people to operate the private trade. ${ }^{29}$ This ecology of information and capital matured during the eighteenth-century and was captured by several diarists, such as William Hickey, who recalled vast profits that ship commanders such as George Chisholm could make by assembling private cargoes. ${ }^{30}$ The account books of the East Indiamen were used to assemble an image of the profitability of the private trade. These records suggest to historians that the private trade was at least as profitable as the monopoly trade of the EIC. But to many contemporaries it was known that the private trade was significantly larger than what the accounts showed, and certainly was larger than the monopoly trade of the EIC. Ship accounts had to be embellished through information from other sources to imagine how much personal fortunes individuals such as Chisholm stood to make through the private trade.

The account books travelled back to Europe, where at the time they found limited traction amongst English legislators charged with making decisions about British India. According to Mary Poovey, the material practices of record-keeping were antipodal to the universalising ambition of abstract theory that was driving administrative decision making around the turn of the nineteenth century. ${ }^{31}$ She claims that much of this accounting material hardly featured in the discussions in the metropole about the manner in which the subcontinent should be ruled. Although it may appear that the official imagination of economic spaces in India in England were based solely on universalising abstractions, evidence from a

\footnotetext{
29 Bowen, 'Privilege and Profit', 49

30 Alfred Spencer (ed.) Memoirs of William Hickey Vol iii (1782-1790) 2nd edition (London, 1923), 215-6

${ }^{31}$ Mary Poovey, 'The limits of the universal knowledge project: British India and the East Indiamen,' Critical Inquiry 31 (2004), 183-4.
} 
later period suggests otherwise. Nineteenth-century financial accounts of territorial spaces if not ship accounts - would later feature in the colonial state's imagination of economic spaces in South Asia (see section 3). The ship accounts did, however, feed into the fictional expectations of the company officials and other non-state actors in this period.

Fictional expectations of the future and the spatialisation of economic spaces in South Asia were further shaped by the discursive travel accounts of Europeans. As the EIC's territorial acquisitions on the Indian subcontinent grew by the early 1800 s, the provincial governments through which the Company ruled its territories commissioned surveys of the newly acquired lands. Francis Buchanan who travelled through the former dominions of Tipu Sultan, the princely ruler from the south who fought the British and aided the French, described in considerable detail the intricacies of a local economy, such as the complicated methods of renting lands by the 'chief farmers' in villages to other 'renters', the taxes that the farmers had to pay, and how the taxes imposed by Tipu to finance his contributions to EIC led to famine and desertion of land by farmers. ${ }^{32}$ Another contemporary, Benjamin Heyne, a surgeon and naturalist from Fort St. George (Madras) journeying through the same region, described how the "commerce of Mysore was in a very languishing state during the reigns of Hyder and Tipoo (sic), because they prohibited all intercourse between their dominions and the Company's territories,' and that 'the greatest discouragement to trade in Mysore is the pointed aversion of the government to assist a merchant in collecting his outstanding debts. ${ }^{33}$ A picture painted by these textual accounts is one where the Indian princes extracted feudal rents, suppressed commerce, trade and enterprise, and where corruption was common because princely favours are bought for a trifling sum.

\footnotetext{
${ }^{32}$ Francis Buchanan, A Journey from Madras through the countries of Mysore, Canara and Malabar... Vol. II (London, 1807), 1, 67.

33 Benjamin Heyne, Tracts Historical and Statistical on India... (London, 1814), 82, 85.
} 
James Prinsep, in contrast, imagined how the British government could make sense of the 'vagueness' of the local economy and the multitude monetary and measurement systems that existed on the sub-continent in the early nineteenth-century. In his treatise on the coins, weights and measures of British India, Prinsep, an assayer at the mint in Calcutta, argued how any government was able to regulate the monetary systems within its own territories by 'supersession of former currencies' but was unable to exert similar control on 'domestic or market weights which are localised under many modifications of prices, customs, and modes of calculation. ${ }^{34}$ In this observation he explicitly draws on the similarities between the metrological chaos in India and in England, where local laws 'rendered cognate its own system, however, different from that of its neighbour. ${ }^{35}$ Nevertheless, he considered that the British government would have a better chance of unifying metrology in India even if they faced insuperable difficulties in doing so. Prinsep's vision for a uniform monetary system and metrology for India influenced weights and measures reforms attempted by the colonial state, eventually culminating in the successful metrological reforms introduced by the nationalist Indian government in $1956 .{ }^{36}$

Prinsep's study of Indian monetary systems was also key in 'discovering' the 'considerable progress made by the ancient people of Hindustan' even before the influence of the Greek civilisation. His motivation for writing about the historical monetary systems of India was partly to exhibit the action of British civilisation on the existing monetary systems. For this project, Prinsep made use of inscriptions, illustrations and translations from the coins themselves to aid others in imagining the richness of past and existing artefacts in circulation

34 James Prinsep, Useful tables illustrative of the coins, weights and measures of British India...(London 1834, 1858), 109.

35 ibid.

36 Aashish Velkar, 'Rethinking Metrology, Nationalism and Development in India, 18331956,' Past \& Present, (advance access 1 Feb 2018), https://doi.org/10.1093/pastj/gtx064. 
alongside the 'standard' rupee being minted under the Regulation VII of 1833 issued by the government of Bengal. ${ }^{37}$ Detailed studies such as those by Buchanan, Heyne, Prinsep and several others gave texture and substance to the images and perceptions of India. They led to the imagining of India, variously, as a country where its people suffered under former princely rule and would find rule by the British liberating in many ways, or as an ancient civilisation with considerable achievements in its past but which would nevertheless benefit from the unifying technologies that British rule could introduce.

Another class of writing that helped to 'make' calculable economic spaces were commercial guides for traders or those interested in the more mundane or practical issues of commerce or administration. William Milburn's 'careful digest of information,' collected during his service with the EIC in India and China, were intended to help its readers visualise the commerce and economic life in these locations. ${ }^{38}$ Writing about Bombay, for instance, Milburn visualises it as an 'emporium of Persia, Arabia, and the western part of India, and where the manufactures and produce of all parts of the world may be readily procured. ${ }^{39}$ Thornton, the editor of Milburn's diary, published his own guide, cautioning readers about the problem of accuracy [in mercantile] calculations. ${ }^{40}$ Along with lists of tables showing exchange rates, Thornton's guide compared the myriad local accounting systems prevalent throughout the Indian Ocean region. In Batavia, on the island of Java, Thornton describes how 'accounts were kept in rix dollars, an imaginary money, containing 48 stivers, and valued at 5 shillings sterling, ${ }^{41}$ Similarly, Thornton finds that 'imaginary money, called

\footnotetext{
37 Prinsep, Useful tables, 69 and plate XLV between 64 and 65.

38 William Milburn, Oriental Commerce or the East India Trader's Complete Guide... (London 1825)

39 Ibid., 124.

40 Thomas Thornton, The East Indian calculator or tables for assisting computation... (London 1823), iii-iv.

41 Ibid., 411.
} 
rupees' is also used to keep accounts in Calcutta. The term, imaginary money, is used to denote the notional value of the currency rather than its specie value: Thornton writes 'all the real specie must be converted to this currency before it is entered into the merchant's book. ${ }^{42}$ Such descriptions were meant to aid those who found themselves encountering the different accounting systems to imagine how trade accounts were kept in terms of the different types of 'imaginary money' a merchant traveller was likely to encounter, and to use this knowledge as insurance against opportunistic behaviour.

To summarise, in the pages of the ship accounts, travel writing and commercial guides, South Asia's economic spaces, akin to Lefebvre's 'markets', are revealed to be social spaces constituted by a historical and complex ensemble of 'commercial relations and communication networks. ${ }^{43}$ Lefebvre himself contends that 'markets' inform ideas about a nation or nation-hood. The making of these economic spaces as national spaces, which in turn led to a national space being recast as a national economic space reveals the violence that Lefebvre observes in social spaces. The production of 'the social,' as Mitchell's 'spatial object, ${ }^{44}$ and the use of planning or forecasts as devices to 'coordinate action and create shared [fictional] expectations about the future ${ }^{45}$ is evident in the Indian nationalist discourse reviewed in the following section.

\section{Visualising India's Political Economy}

The expansion of colonial space, Goswami claims, was concomitant with the generating, consolidating and reflexive use of a body of discursive knowledge for the reproduction of

\footnotetext{
42 Ibid., 425.

43 Lefebvre, Production of Space, 111-2.

44 Timothy Mitchell, 'The Stage of Modernity,' in Timothy Mitchell (ed.), Questions of Modernity, (Minneapolis and London, 2000), 1-34: 26.

${ }^{45}$ Beckert, Imagined Futures, 217.
} 
state power. ${ }^{46}$ This body of knowledge has been variously described by historians who nonetheless agree on its foundational elements: systematic accumulation of statistics, detailed practices of record-keeping and the legitimisation of colonial practices based on the institutionalisation of colonial knowledge. In this context, accounting practices were recruited by state actors as tools for governance and rule. Statistics, records and accounts also functioned as devices to imagine the colonial space in economic terms: the budgeting, auditing and diagnostic elements of colonial accounts helped to produce an 'official' visualisation of India as an economic space, one that needed to be ruled in particular ways in order to generate acceptable returns on the investments made by the colonial state (figure 3).

Where the colonial state in India imagined an economic space generating economic return, this same body of knowledge was used by early nationalists to invoke the notion of drain of wealth from India. Such imagining of wealth drain is evident in the writings of Dadabhai Naoroji and Mahadev Govind Ranade, two of the early Indian thinkers who developed a deep understanding of western economic thought as well as the functioning of the colonial modes of production of economic knowledge. Paradoxically, the more the colonial state displayed what Weber would later term as capitalist rationality - effectively rendering economic spaces calculable - more the nationalists such as Naoroji and Ranade claimed that the colonialist state displayed mercantilist rationality by being fixated with draining wealth and resources from India. The conflicting notions of India's political economy - Lefebvre's violence of social spaces - reveals how the same body of knowledge could be recruited in diametrically opposing ways of imagining the economic space in India.

The nationalists presented an alternative to the western trajectory of modernising, a hybridisation of science, politics, social reform and economics: their vision called for

\footnotetext{
46 Goswami, Producing India, 74-5.
} 
differently imagined ways of ordering future Indian society. This ordering had to offer an alternative way of thinking compared to the colonial or western forms of economic knowledge. The Indianisation of western economic thought was a pre-requisite to how those who sought to shape economic space on the sub-continent imagined these future spaces in the context of swarajya (self-rule) and swadeshi (indigenous manufacturing). The following paragraphs first briefly review the official colonial imagination before drilling down into the writings of Naoroji, Ranade and other nationalists to demonstrate my argument.

The government's official financial statement for 1888-89 reported on the slow growth in revenue from India which was 'a poor return for the money which the government has spent in improving its estate. ${ }^{47}$ Such statements are indicative of how the colonial government had officially come to imagine India in financial terms. The statement concluded that the colony had the potential to generate a 'handsome increase of revenue' if new practices were introduced. ${ }^{48}$ The emphasis on accounting and accountability generated a discourse on the Indian economy within a new, modernist framework of vast amounts of statistical data, which, combined with innovations in accounting techniques permitted the visualisation of an unified economic space in quantitative terms. ${ }^{49}$ Just like the mercantilist trade accounts presented an imagined ordered space out of the chaos of commercial life (section 2), the new styles of classification and new forms of taxation that constituted colonial regulatory practices enabled the new generation of rulers to imagine India as a spatialised economic entity.

47 'Financial statement for 1888-89,' Supplement to The Gazette of India, No 13 (Calcutta, March 31 1888), 539-607: 548.

${ }^{48}$ Ibid.

${ }^{49}$ U. Kalpagam, 'Rational calculations and idea of the "Economy",' Economic and Political Weekly 32 (1997), PE2-PE12: PE2; U. Kalpagam, 'Colonial governmentality and the “economy”,' Economy and Society 29 (2000), 418-438: 434. 


\section{INSERT FIGURE 3 HERE}

The sub-continent's economic spaces were to be simultaneously deciphered and protected by the colonial rulers. B. H. Baden-Powell, cautioned that any student 'who approaches the subject of Indian land-tenures, and land revenue systems in British India, has probably a vague idea that he is about to enter on a terra incognita or to plunge into some mysterious and unintelligible darkness. ${ }^{50}$ The vast body of knowledge being generated by the colonial administrative machinery was meant to help the uninitiated navigate this space, to help understand the very notion of India as a nation-space, and to comprehend how its physical, topographical geographies mapped onto its economic geographies. Concomitantly, this same knowledge could be used to devise ways of protecting the physical and economic spaces.

The connections between the physical, topographical and economic spaces in the colonial imagination - or how the British 'gazed' their empire space - can be illustrated through the remarkable example of the Inland Customs Line. The Line was a physical barrier constructed to protect the state's revenues from taxation on commodities such as salt. The manufacture of salt was a state monopoly that lasted throughout the colonial period until the twentieth century. The colonial rulers erected a 'huge material barrier' extending 2500 miles across the sub-continent. It consisted of 'thorny trees and bushes, stone walls and ditches and was guarded by an army of 12,000 officers. ${ }^{51}$ The barrier was designed to keep out salt produced in the non-British regions, that is from neighbouring princely states, from entering the British Indian territories and thereby circumventing the state monopoly. The Inland Customs Line gave a material form to the imagined political and economic space that was

\footnotetext{
${ }^{50}$ B. H. Baden-Powell, The land-systems of British India (Oxford, 1892), 1.

${ }^{51}$ Romesh Chunder Dutt, India in the Victorian Age: An economic history of the people (London 1904), 524-5.
} 
colonial India, and was a means of protecting the dissipation of state revenue and financial return from this economic space. In this way, the exercise of colonial rule, as Appadurai suggests, involved 'the colonial imagination and that in this imagination [measurements] played a crucial role. ${ }^{, 52}$

Indian thinkers, such as Dadabhai Naoroji, became highly critical of this visualisation of India's economic space under colonial rule: spaces to rule, protect and generate economic returns. He thought colonial rule of this nature led to India 'suffering seriously in several ways. ${ }^{53}$ Naoroji was the first Indian professor of Mathematics and Natural Philosophy in Bombay in 1854, the first Indian to establish a business presence in England in 1855, first Indian to become a professor at University College, London, and the first Indian to be elected as an MP from the London constituency of Central Finsbury in 1888 (figure 4). ${ }^{54} \mathrm{He}$ devoted himself to the study of finances of the government of British India and to the connection between British taxation and poverty in India. Where the colonial administration considered the revenue from India as return on investment, Naoroji visualised it in terms of 'a drain of profits from India to England. ${ }^{55}$ This drain of resources was contributing to the dependency or disability within India: 'we are sinking fast' wrote Naoroji. The 'un-British rule', as he saw it, was being 'destructive and despotic to India and suicidal to Britain', despite the 'immense importance of India to Britain for Britain's own greatness and prosperity. ${ }^{56}$ Naoroji visualised India as an economic space whose wealth was being drained by a despotic

\footnotetext{
${ }^{52}$ Arjun Appadurai, 'Number in the colonial imagination' in Modernity at large: cultural dimensions of globalization (Minneapolis, Minn., 1996), 114-135:115.

${ }^{53}$ Dadabhai Naoroji, Poverty of India: papers and statistics (London 1888), 1.

${ }^{54}$ David Lewis Jones, 'Naoroji, Dadabhai (1825-1917)', rev. Oxford Dictionary of National Biography, Oxford University Press, 2004

${ }^{55}$ Naoroji, Poverty of India, 30.

${ }^{56}$ Dadabhai Naoroji, Poverty and Un-British rule in India (London 1901), iii-iv.
} 
administration acting in contrast to the values ensconced within the larger British society: a view that was crystallised between 1873 and 1901.

\section{INSERT FIGURE 4 HERE}

The collision between the two imaginings of India, would shape the political economy, nationalism, and the independence movement in India after c1890. The divergent imagining of India's political economy within the British and the Indian economic thought had become fairly evident by the time Mahadev Govind Ranade's essays on Indian economics were published in 1906. At a lecture he gave at Deccan College, Poona, in 1892, Ranade (figure 5) outlined his vision for a new political economy for India. ${ }^{57}$ On this occasion, he gave an eloquent review of the "past and contemporary history of the growth of economic science in England, France, Germany Italy and America' and argued that contrary to the views of English economists of 'the Ricardian School' economic principles were not universally and necessarily true 'for all times and places, and all stages of advancement.' This observation, that economic principles were not universal, led to his reflection that 'the divorce of theory and practice is a mischievous error. ${ }^{58}$ He imagined theory to be enlarged by practice and practice to be theory studied in relation to 'proximate causes.'

As Indian thinkers such as Ranade imagined the embedding of economic principles in the 'actual practices', their imagining of India's history became an important device to understand India's 'old legacies and inherited weaknesses. ${ }^{59}$ Ranade was a scholar of the history of the Maratha empire, which had ruled large parts of the Indian subcontinent as the Mughal empire began to wane in the late seventeenth and early eighteenth century. He gave

\footnotetext{
${ }^{57}$ Mahadev Govind Ranade, 'Indian political economy,' in Essays on Indian economics: a collection of essays and speeches (Madras 1906), 1-42.

${ }^{58}$ Ibid., 22-24.

${ }^{59}$ lbid., 24
} 
considerable thought to the historical 'lessons as to why a more organised foreign power [the British] had displaced the disorganised native power from its position as supreme ruler. ${ }^{, 60}$ His reading of the Maratha history led Ranade to conclude that Indian laws and institutions 'favour a low standard of life, and encourage sub-division, not concentration of wealth. ${ }^{61} \mathrm{He}$ further reasoned that Indian (Hindu) religions had historically condemned the ardent pursuit of wealth as a mistake to be avoided as far as possible. The intermeshing of ancient laws, culture and religion meant that India's economic spaces were marred by stagnation and dependence, depression and poverty: 'drain on wealth and talent through foreign subjugation are written in broad characters on the face of the land and its people. ${ }^{62}$

\section{INSERT FIGURE 5 HERE}

The relevance of such visualisations of India's history - of the Maratha attempts at territorial unification and their subsequent defeat by the British - and its effect on India's political economy was, to Ranade, an illustration not only of why India remained poor but how historical attempts were made to cement the 'union of Indian races' into a national space. That the historical attempts remained unsuccessful should not deter future projects, Ranade argued, as he imagined unified social and religious spaces along with a political economy for India built by 'asserting its independence, animated by patriotism, and [a vision] to see far into the future of the possibilities open to a federated India., ${ }^{, 63}$

Naoroji, Ranade and Romesh Chunder Dutt were among the early pioneers who turned to history in order to critique British rule in India as well as to construct an economic thought that was appropriate to Indian conditions. Imagination of the past and visualisation of

\footnotetext{
${ }^{60}$ Mahadev Govind Ranade, Rise of the Maratha Power (Bombay 1900), i.

${ }^{61}$ Ranade, 'Indian political economy', 24.

62 Ibid.

${ }^{63}$ Ranade, Rise of Maratha power, iv and 16.
} 
an alternate form of political economy led such writers to propose new concepts that steered away from a universalising form of economic knowledge. Their legacy was inherited by a later generation of Indian thinkers who would further diverge from western notions of political economy.

South Asian economic spaces were the locus for control and dominance of future economic relationships which previously were visualised in particular ways by the dominant colonial culture of the period. Some nationalists held the notion that India's future lay along the 'middle path': a path that involved the 'large scale application of science to industry' but also one where the 'spinning wheel and the bullock cart' were protected so long as the 'state cannot provide for the victims of unemployment'. ${ }^{64}$ This duality required far more imaginative ways of ordering future Indian society than the western economic thought could offer, argued the nationalists. The generation of Indian thinkers, who inherited the intellectual ideas of Naoroji and Ranade, framed the discourse surrounding the political economy of India in at least two directions: they stressed the importance of political self-determination and the need for planned economic development. In this regard, the ideas developed by $\mathrm{C}$. Vijayaraghavachariar and $\mathrm{M}$. Visvesvaraya reflect the maturing of the nationalist movement during the 1920s and 1930s. Later, the ideas of P. C. Mahalanobis on statistical techniques would set the direction of national planning after political independence in 1947.

Vijayaraghavachariar advocated the need for a written constitution for India, which took into account the ancient Hindu idea of polity. His vision for an India that would be selfgoverned was cognizant of the developments in political philosophy (especially those emerging from the French revolution and the American independence movements) as well as his understanding of the Hindu shastras, the ancient, vedic texts that were considered to be

\footnotetext{
64 'Editorial: Science and Culture', Science \& Culture, i (1935), 1-4: 1, 4.
} 
the basis for Hindu law. 'The ancient Hindu [rulers] were not the maker of laws; [the law] evolved from shastras and was supplemented by customs and usages and the whole interpreted by judges', he argued. ${ }^{65}$ This way of imagining ancient Indian polity - and nationspace - resonated with the institutionalist ideas of Ranade, who had argued about the relevance of Indian history for imagining the possibilities for a future independent India. But Vijayaraghavachariar would go further by invoking the achievements of ancient Indians in the areas of 'art and science to which Europeans have not done full justice':

'Hindus not only produced philosophy, religious and secular, but it was the Hindus who invented the system of decimal fractions, algebra, and the game of chess. The system of civil administration was perfected to a degree rarely reached in modern times. ${ }^{66}$

To Vijayaraghavachariar, history was meant to aid the process of analysis of the present and in turn shape future expectations. ${ }^{67}$

As the idea of planned development steadily took hold amongst other nationalists, Visvesvaraya, a noted engineer, a senior civil servant in the princely state of Mysore, elaborated on the principles of economic planning in $1934 .^{68} \mathrm{He}$ equated planning with 'exercising forethought in respect of economic needs. ${ }^{69}$ Thinkers such as Vijayaraghavachariar and Visvesvaraya painted a picture of a new, modern nation built along technocratic ideas, but one that retained its ancient, cultural heritage. Such imaginings would

\footnotetext{
${ }^{65}$ Presidential Address, Indian National Congress, 26 December 1920, reprinted in Indian Annual Register, 1921 ii, part iii, 125.

${ }^{66} \mathrm{Ibid}$.

${ }^{67}$ Ibid. 129

${ }^{68}$ M Visvesvaraya, Planned Economy for India (Bangalore 1934).

${ }^{69}$ Ibid., 251-52
} 
appeal to later nationalist leaders such as Nehru, when economic planning became crystallised first as part of the independence movement, and later as part of independent rule.

Not all nationalists imagined a future for India that was technocratic or urbanised. In fact, the conflict or violence that was part of the recasting of India's national economic space was not entirely between racial groups (European colonists and native Indians) or strictly between economic classes (bourgeoisie upper castes and proletariat lower castes). Rather contrary expectations amongst the nationalists themselves involved preserving the imagined dynamic of a rural economy that had been captured by observers in the nineteenth century. Bholanauth Chunder, an Indian employee of the colonial administrative service, who travelled from Calcutta to Delhi in the 1860s, describes how the religious 'melas' or festivals were vibrant spaces for rural markets and fairs: 'the mela is particularly remarkable for being a great cattle-fair', he wrote: 'cows and calves, ploughing oxen, cart-bullocks and buffaloes sell to the number of some thirty thousand. Not less than ten thousand horses change their masters. The congregation of men may be estimated at near two hundred thousand. ${ }^{70}$ Travel accounts, like those provided by Chunder, or the glossaries of 'peasant life' compiled by William Crooke, a European civil servant in the late 1870s, gave form to the intermeshing of economic, social and religious lives of Indians. ${ }^{71}$ These visualisations fed into the imaginations of later nationalists, such as M K Gandhi, who, in the 1930s, commissioned a series of murals by the artist Nandalal Bose depicting scenes of the rural economy and rural markets. The object of such visual art was to imagine a more sanguine India, the real India of the past and the present that was relatively unsullied by colonial technology or by industrial

${ }^{70}$ Bholanauth Chunder, The travels of a Hindoo to various parts of Bengal and Upper India (London 1869), 122.

${ }^{71}$ William Crooke, A Glossary of North Indian Peasant Life (Allahabad, 1879 [Reprinted Delhi, 1989, ed. Shahid Amin]). 
development; an image of a future, independent India that nationalists such as Gandhi aspired.

Between 1937 and 1941, Nehru and like-minded nationalists imagined the activity of national planning to include not just the economic objective of raising the material standard of living, but also to include the cultural and spiritual values as well: 'I cannot conceive of planning except on this wider basis and always with a view to the advancement of human welfare in the widest sense of the term,' he later recalled in $1953 .^{72}$ In this kind of an imagined 'tryst with destiny' for India, Nehru sought to strike a balance between 'material advance and other possible goals. ${ }^{73}$ However, where Ranade, and Vijayaraghavachariar had invoked historical achievements to connect with self-rule in India's future, post-independence nationalist thinkers began to use the technocratic language of macroeconomics to imagine India's future. When P C Mahalanobis, the erudite promoter of analytical statistics in South Asia, became involved with the problems of national planning through his stewardship of the Planning Commission in the 1950 s, he used his approach to analytical statistics 'primarily as an aid to clear thinking on my part' and to help 'others like me' who sought to use statistical methods to study the issues of national income growth. ${ }^{74}$ The forward-looking approach favoured by this generation of statisticians and economists in the mid-twentieth century was that rapid growth or accumulation of national income should occur through industrialisation and that it should take place under central planning.

\footnotetext{
72 Jawaharlal Nehru, Letters to Chief Ministers, 1947-1964, 5 vols. (Delhi, 1988), vol. iii, 388.

73 Ibid., 390.

74 P C Mahalanobis, 'Some observations on the process of growth of national income,' Sankhya: The Indian Journal of Statistics (1933-1960) 12 (1953), 307-12: 308
} 


\section{Conclusion}

This case study of colonial India has shown how integral economic space-time was to the constitution of national spaces and to how historical actors imagined their future worlds. Although recent literature has called for recognising the primacy of time in studies of capital or capitalism, spatial scales continue to remain key in historical narratives of economic spaces. As Mary S. Morgan observes, 'the problem of scale and size with respect to the human observer mean we can only see a little bit of an economy at a time...a bit like an exercise in cartography. ${ }^{75}$ To make a 'whole' from these spatial 'parts' requires skill, intuition and imagination, she argues. ${ }^{76}$ I have argued that the process of imagination to fill in the gaps reveals the ensemble of cultural, social and technical practices that actors use. The economic spaces that are imagined are, on occasion, shaped by the violence and conflict stemming from the different practices and fictions that historical actors introduce. Whilst it is important to recognise the boundaries of these spatial artefacts, it is simultaneously important to decipher the processes that shape and give form to the images of such social spaces.

75 Mary S Morgan, 'Seeking Parts, Looking for wholes,' in Lorraine Daston and Elizabeth Lunbeck (eds.) Histories of Scientific Observation (Chicago and London 2011), 303325: 305.

${ }^{76}$ Morgan, 'Seeking Parts', 319. 
Imagination and Rule

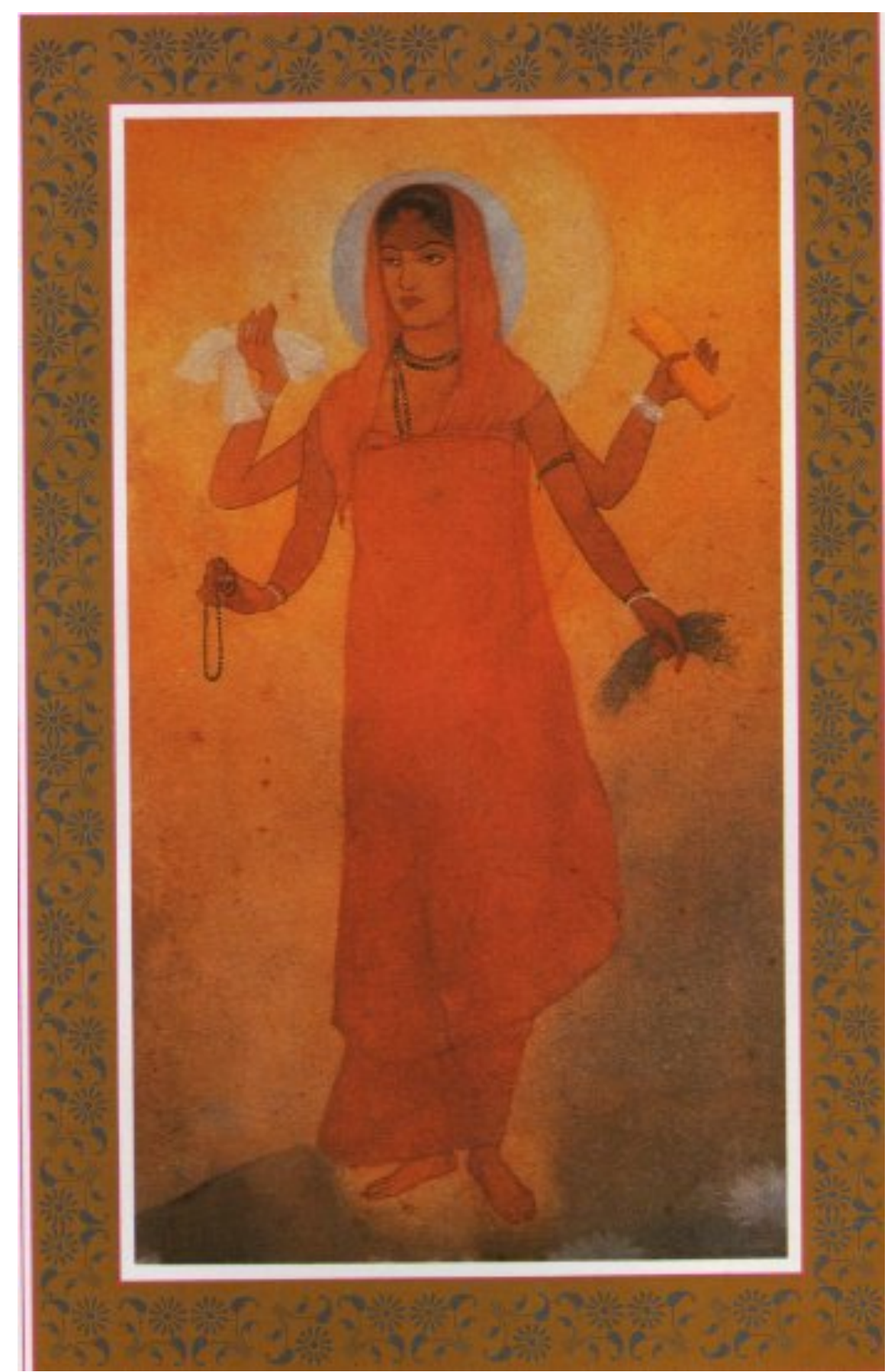

Figure 1

Painting by Abanindranath Tagore (1871-1951) made in 1905. This is one of the earliest visualizations of Bharat Mata, or "Mother India" as a saffron clad woman, holding a book, sheaves of paddy, a piece of white cloth and a garland. It imagines India as a nation unified by its industry, spirituality, learnedness and ecology.

Source: Wikimedia Commons 


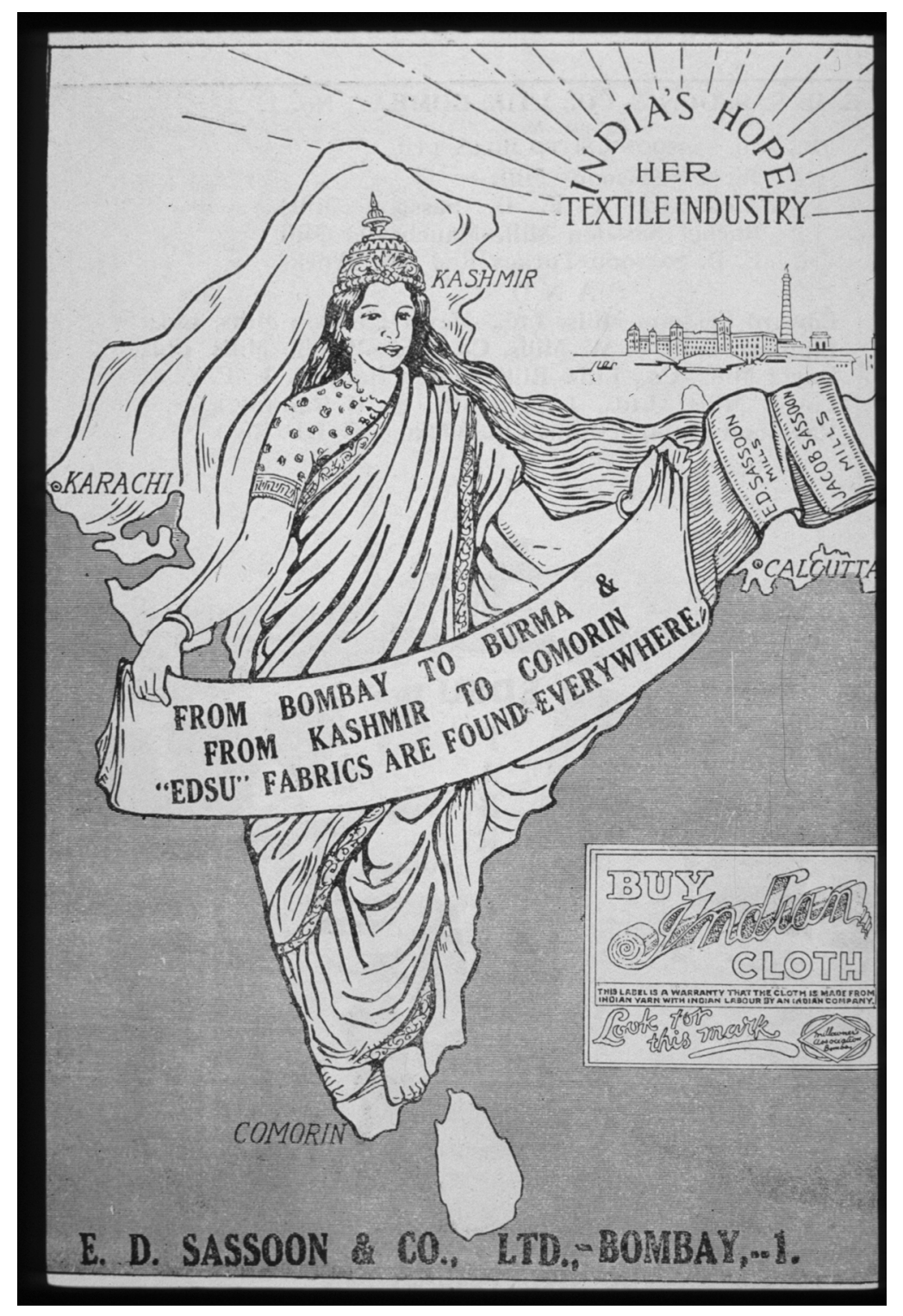

\section{Figure 2}

India's Hope: Her Textile Industry. Advertisement for E. D. Sassoon \& Company, Bombay, 1931, visualising a 'hopeful' future for the nation through self-rule (swarajya) and indigenous (swadeshi) industries. The spatial boundaries of this national economic space are explicitly mentioned.

Source: Bombay Swadeshi League, 1930; Image courtesy Lisa Trivedi 


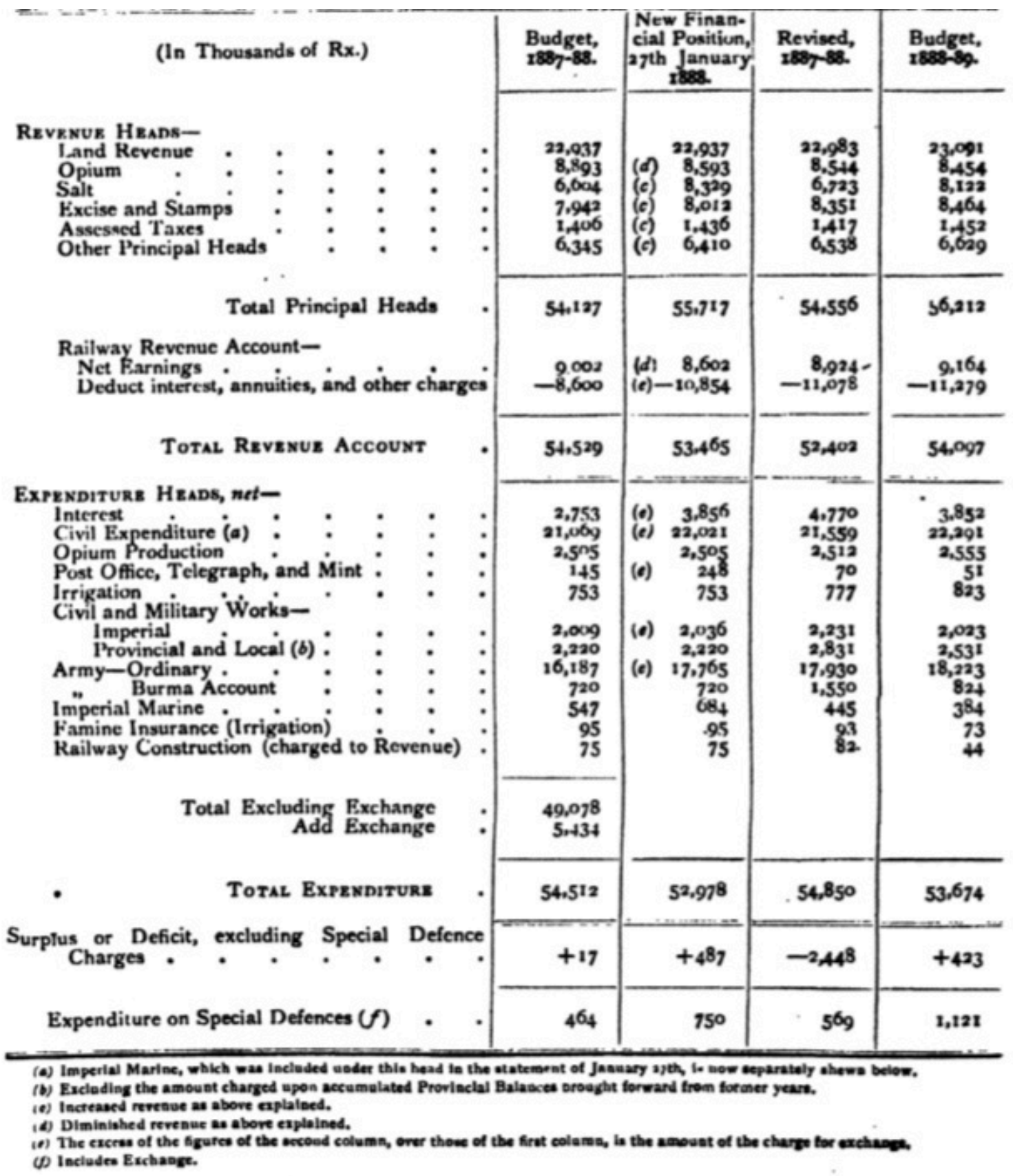

\section{Figure 3}

Details of the 'national' income and expenditure by the colonial Government of India showing the visualization of British India as an economic space. Source: 'Financial statement for 1888-89,' Supplement to The Gazette of India, No 13 (Calcutta, March 31 1888), 539607: 544 


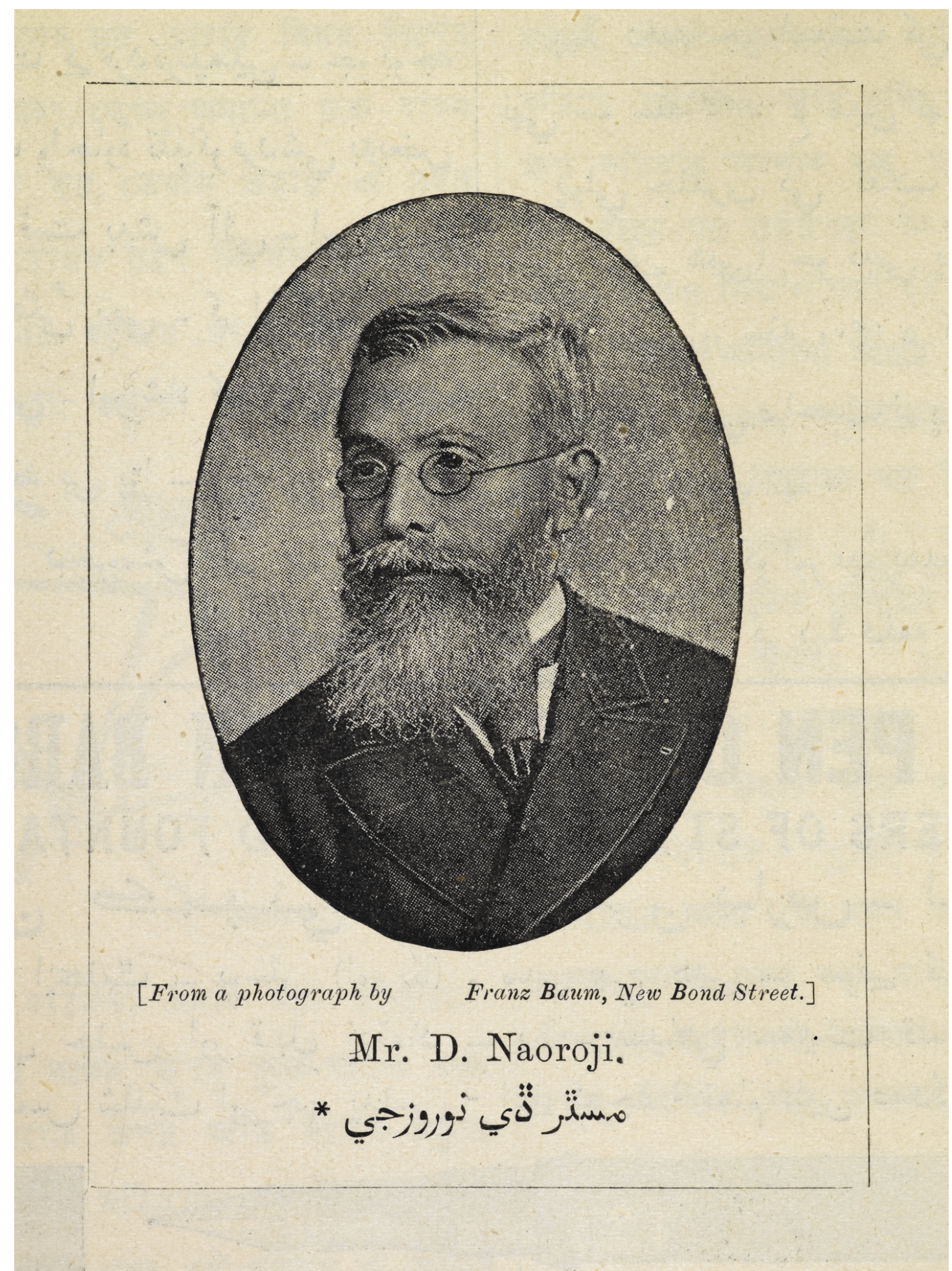

Figure 4

Photograph of Dadabhai Naoroji (1825-1917) from 1892, the year he was elected as the first Asian MP to the British Parliament.

Source: The British Library Collection, 14119.f.37 
Imagination and Rule

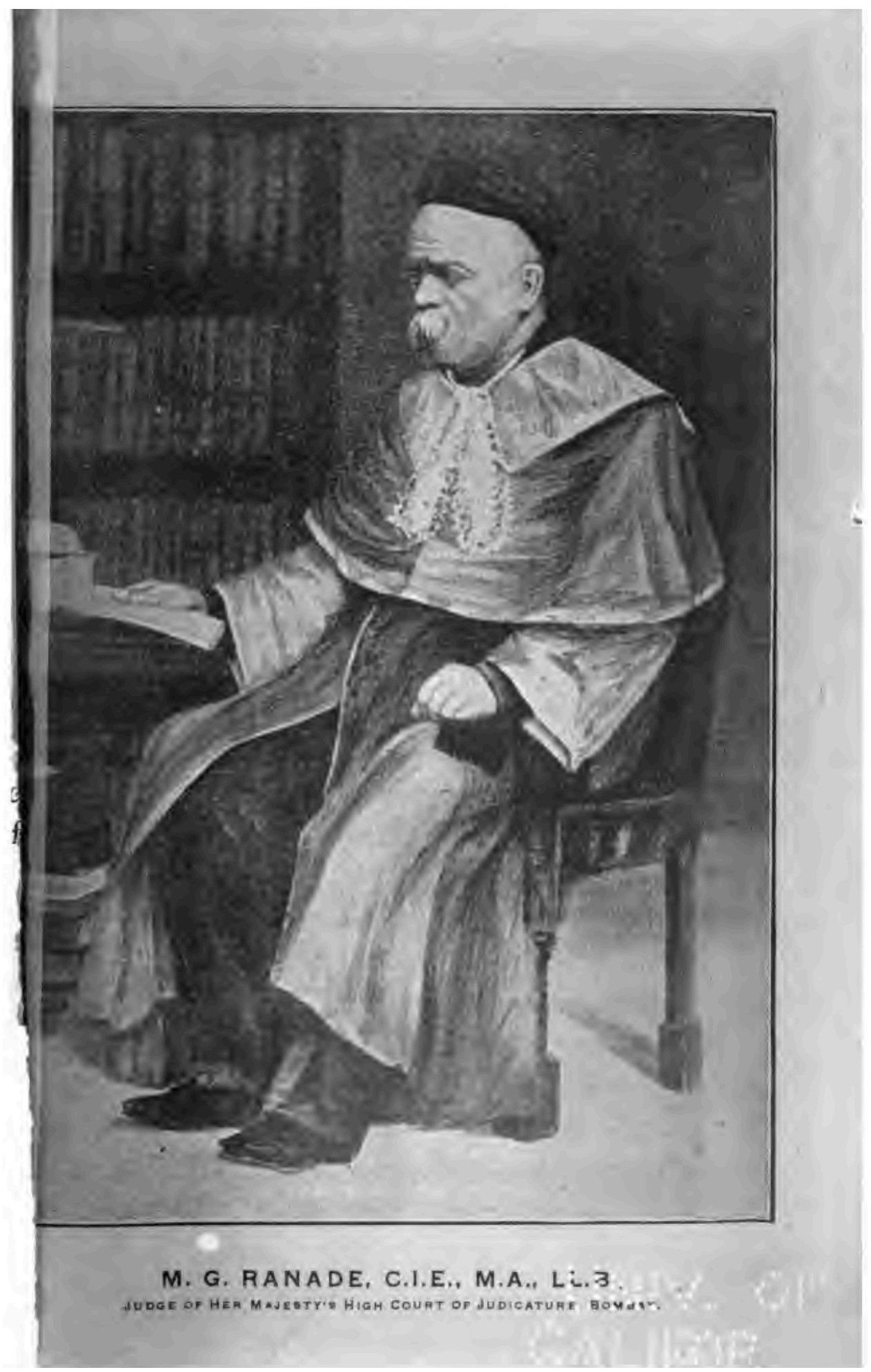

\section{Figure 5}

Photograph of Mahadev Ranade (1842-1901) attired as a judge in the Bombay High Court. Although a lawyer by profession, he was also an economist and a historian. Source: Mahadev Govind Ranade, Essays on Indian economics: a collection of essays and speeches (Madras 1906), Frontispiece. 